\title{
Research of Roof Space Development and Utilization in Universities
}

\author{
Wenjun Wang ${ }^{1, a^{*}}$ and Hongxing $\mathrm{Yi}^{1, \mathrm{~b}}$ \\ ${ }^{1}$ City College of WUST, Wuhan, China \\ aWangwenjun2016hy@163.com, blucyyhxc@163.com
}

Keywords: Roof space; Campus building; Rationalized utilization; Design principle

\begin{abstract}
Through the research, the paper discussed the reasonable use of the campus building's roof space, and proposed principles and methods in design. Analyzed and looked forwards into the development of roof designing, landscape design, and improvement practice and development tendency. Provided a valuable reference for the design of the "fifth facade" of buildings, and made suggestions on how to create the "roof culture" in universities.
\end{abstract}

\section{Introduction}

Colleges and universities, as an important personnel training base in the nation, is a material carrier of higher education. It's not only for the basic task of the teaching and scientific research, but is also the important platform of information exchanges and cultural transmission, and it is an important link in transforming the knowledge into productivity as well. University is like a small society, where the young students establish their own view of life and value, learn to think and more important, and learn to live. So, the campus should not just create a good physical environment for the students, but also to provide a conducive mental friendly atmosphere for learning and communication. To build a pleasing physical environment and spiritual atmosphere the design should embody abundant landscape and activity space in campus. With the fast development of higher education and the continuous expansion of university enrollment in China, the campus becomes more crowded and the education resources are in shortage. Most of the campus runs short of land area and lack of enough space for further development. There is not enough space for sports activities and study exchanges in the daily life of university students. Therefore, it is necessary and imperative to make full use of the roof space in campus.

\section{Existing Situation}

With the three-dimensional development of the campus building, the campus space is in complexity and diversity, and the disadvantages of campus building's roof area emerge. Like all the other residential building and office tower in the city, venting systems, stairwells, and air conditioners occupies most of the roof space. Then it becomes boring and crude. Therefore, how to change the monotonous and featureless character of campus building and make full use of the building's roof space to create a characteristic culture is particularly important. Because only through this method can we create a new campus atmosphere and culture of the roof.

According to the current research domestically and internationally, more and more people are exploring and doing the research on improving roof structure of the residential and office towers in the city, such as the heat preservation, heat insulation, and energy saving etc. In fact, the roof space can be the "fifth facade" of the building and an important part of the skyline of the city. The current research on utilization of the campus roof space is quite few, which needs to be discussed and studied.

\section{Existing Problems}

With the development of society, the expansion of building structure and car parking dominates the green space in campus. The green area is shrinking, the height of campus building is growing while its "fifth façade" changing into messy. The floor in the roof area is dark due to the water proof 
painting, and the massive equipment covers large area. Nowadays the "green roof" movement in the city is developing prosperously, but the roof space in campus does not keep up with the pace of social development.

Many architecture designs at present become more identical, under this background; the design of roof space didn't get the attention they deserve. The reasons and the major influence factors are as follows:

Safety. Safety is one of the main reasons why the roof space in colleges is in low utilization. Now an increasing number of buildings in campus are high-rise towers and many accidents of university students falling from buildings appeared correspondingly. For the safety of the students, campus authority decides to lock the door to the roof. They prefer to abandon the effective development and utilization of roof space to avoid the unexpected accident.

Climate. The influence of climate factor is also a main reason for the low utilization of the roof area in universities. Through the analysis of the outstanding cases of roof area development, we get a conclusion that the roof space get better used in the subtropical and tropical areas, where people realize that the roof design not only can improve the indoor physical environment, but also can improve and increase the outdoor activity space. That may be affected by the climate in the north area of China, where the consciousness of the roof space utilization is relatively weak. Because of the cold weather in winter and flying sand in windy days, the utilization of roof space is basically in a blank state.

Structure. Another reason of the low utilization of roof area is the structure of building. Most designs of existing architectural buildings only consider the low amount of load on the roof; therefore, large amount of load on the top will affect the stability of the structure. So, it is a major problem that needs to be solved when doing the reconstruction work on the roof.

Noises. Take the usage of the roof space will produce a certain noise, which may cause some influence in the interior area. The influence is more obvious especially in teaching and laboratory buildings; therefore, we should set up relatively static exterior space on the roof of those buildings.

Cost. As a non-profit organization, the investment funds of universities are from the government. The funds are mainly used for improving infrastructure and indoor facilities on campus, which also leads to the pursuit of the optimization of the indoor environment, the construction of the infrastructure, and the ignorance of the roof space development.

\section{Design Suggestions}

University campus is a cradle of fostering talents. The campus environment development should be sustained to stimulate the creativity of students. The vitality and continuity of should not only meet the needs of the diverse development of society, but also the perspectives of culture, landscape, and function to promote the healthy development of the campus. Outdoor activity space in campus is shrinking. More teaching buildings are in construction. We need to slow done and start to think and study the reform of the roof space and explore the principles of reasonable utilization of roof space in campus, and let the roof space in campus fully reflect its regional and cultural characteristic of a campus instead of blindly convergence.

The planning and development process of university campus is not isolated, static, or one-sided, but it is based on the needs of social development. However, the fast development and expansion of university makes the original planning almost in "saturation", so to compensate the activity space that the other facilities of campus seized, we need to develop vertically instead of horizontally. Therefore, how to design vertically and integrate the campus's culture, landscape and function is the main question need to be discussed.

"Cultural context" is one of the targets for landscape art. It emphasizes the continuity of time and space of the individual and integral landscape environment in specific area, namely harmonious dialogue relations. There are two concepts in campus cultural context: "synchronic" and "after", one refers to the effect that occurred under the background of synchronic interaction with the environment; the other one under the background of its development history. 
Ecological Characteristics. The landscape and activity space in campus reflects the vitality of it and the daily life of the students and teachers. So, different from the planning of a large-scale landscape area, the landscape in roof space design should be environmental friendly, try to balance the diversity of ecological and the active atmosphere.

Cultural Characteristics. The landscape design in university campus should be people-oriented and care about everyone, rather than just grand to give a visual shock. University records the traces, and the development of the region. It is a strong historical and cultural accumulation in the city, and the campus landscape is the record of the historical trace of as a symbol. So, when doing the landscape design in university campus, we should continue the existent cultural context, geographical features, and its history. We should not to go in for the grandiose projects and blindly follow and imitate the foreign campus. Otherwise, we will finally build a large scale of green land without any characteristics. Forget this method, as it is not the right standard for a pleasant landscape space. It will bury the valuable cultural wealth that forms by years. To prevent this huge lost, we should make reasonable use of the roof space and create a landscape area there with its own special characteristic, and provide a comfortable communication space to people. This will not only for the benefit of the expansion of landscape in campus but also the cultural diversity of the campus.

Stress Communication Space. The landscape area in university campus is different from others, we should pay more attention to achieve the function of communication. Because the main users are the students, they have regular life style in learning, communication, and other sports. If we can create a pleasant roof landscape space, it will encourage more communication and knowledge exchange activities between teachers and students. The traditional large scale of landscape area lacks privacy, while a cozy and semi-open landscape space will make people feel more comfortable. Therefore, to build a pleasant and comfortable communication and landscape area in the roof will help to cultivate the imagination of students.

Individual Features. The landscape area in Universities provides an outdoor activity space that helps to form the personality of students. With the fast development of modern information in society, the students tend to pursue the individuality and freedom; therefore, we should comply with the demands of the students and to build a pleasant landscape area that can meet the needs of them in learning and after school life. Nowadays, the design and development of the existing landscape lacks personality and characteristics. The appropriate scale of roof space provides an excellent challenge in designing a creative and featured landscape space for students. Innovative personality touches the landscape garden in campus roof, which can provide a comfortable communication space and help to form the individual "roof landscape culture".

\section{Conclusion}

The roof space design should pay attention to the diversification and three-dimensional concept. The should pay attention to the open space and the intermediary space in the exterior area, and increase public space for information and exhibition in the internal. In the external area, the design should use the "gray space" concept to build a communication space. We can create the communication space in the aerial corridor, roof platform, and the setback area in the roof. For example, we can extend the classroom to the external terrace and combine the internal and external space to build a personalized learning space, and at the same time cultivate the creativity of students.

Roof space design can also form a personalized outdoor teaching area to meet various needs in teaching. For example, in professional art sketch classes, students need to improve their portrait abilities through painting, usually they paint the plaster figures, fruits, or bottles and jars indoor, but sometimes, the students still need to be taken out to draw outdoor to feel the relations between lighting and shadow. While in science and engineering classes, some experiments may cause air or sound pollution indoors, so set the experiment class in the roof space can be effectively avoid the pollution of interior space. Therefore, colleges should better make reasonable use of roof space. 


\section{References}

[1] G.Y. Shen: Urbanism and Architecture, Vol. 3 (2008), p.10.

[2] W.M.Zhao: Theory and Method of Mountain University Campus Planning (Huazhong University of Science \& Technology Press, China 2007), p.68.

[3] L.Ouyang: Modern Art and Design, Vol. 4 (2002), p.26.

[4] Y.B.Chen: Green Campus (China Architecture \& Building Press, China 2012), p.86.

[5] G.Y.Huang, L.Y. Huang, N.Chen: Journal of Chongqing Jianzhu University, Vol. 27 (2005), p.2.

[6] Clare Cooper, Carolyn Francis: People Places Design Guidelines for Urban Open Space (China Architecture \& Building Press, China 2001), p.183.

[7] L.L.Sun: Research of A Pattern for Communicational Space in Colleges (MS., Southeast University, China 2007), p.55.

[8] Jan Gehl: Life between Buildings (China Architecture \& Building Press, China 2002), p.105.

[9] Theodore Osmundson: Roof Gardens History Design and Construction (China Architecture \& Building Press, China 2006), p.140.

[10]T.Yu: The Design Principle and Design Tactics Research of the Campus Space (MS., Huazhong University of Science\&Technology, China 2004), p.28.

[11]H.Ma: The Development and Use of The Roof Space (MS., Tianjin University, China 2005), p.57. 